\title{
Evaluation of the medical care quality indicators for the pharmacotherapy of patients with ischemic stroke: a hospital-based study
}

\author{
Oksana Levytska ${ }^{1}$, Bohdan Hromovyk ${ }^{1}$, Tetiana Ryvak ${ }^{2 *}$, \\ Kateryna Kostyana ${ }^{2}$
}

\author{
${ }^{1}$ Department of Organization and Economics of Pharmacy \\ ${ }^{2}$ Department of Clinical Pharmacy, Pharmacotherapy and Medical Standardization \\ Danylo Halytsky Lviv National Medical University, 79010, 69 Pekarska str, Lviv, \\ Ukraine
}

*Corresponding author: Tetiana Ryvak, e-mail: tanusha1905@gmail.com

\begin{abstract}
Ischemic stroke belongs to the leading causes of death and disability in the world and Ukraine. The surviving rates depend on the quality of the provided medical care.

The research aimed to analyze the quality of medical care related to pharmacotherapy of ischemic stroke. The clinical indicators for quality are the quantitative or qualitative indicants that have evidence or consensus of direct influence on it. Six of them relate to acute ischemic stroke pharmacotherapy (namely, thrombolytic, antiplatelet, anticoagulant, and lipid-lowering agents use at different stages of hospital stay) and were investigated in this retrospective analysis of 151 patients' medical records of one of the specialized hospital departments in Lviv city.

The clinical indicators for quality of medical care showed that pharmacological treatment using antithrombotics (antiplatelets and anticoagulants) at the admission to the hospital corresponded to standards and quality was defined as high with rates of $65.6 \%$ and $85.4 \%$. At discharge, the indicator analysis of pharmacotherapy revealed existing problems for antithrombotic ( 2 indicators) and lipid-lowering (1 indicator) pharmacotherapy with rates of $33.3 \%$ and $47.7 \%$.

The outcomes concluded the existence of problems related to pharmacotherapy. The complex of three algorithms was introduced to improve the quality of medical care.

Keywords: ischemic stroke, quality of medical care, medications, pharmacotherapy, clinical indicator for quality.
\end{abstract}




\section{Introduction}

Ischemic stroke is one of the most widespread disorders with high death rates among the population all over the world. It is projected to increase. As a major public health burden and a leading cause of serious long-term disability $(1,2)$, it requires timely medical care of the good quality that corresponds to the current evidence-based clinical guidelines $(3,4)$. Despite the limited data, several studies show that medication errors are common among patients hospitalized for acute ischemic stroke revealing 4-19\% inhospital incidence rate of those $(5,6,7,8)$. To prevent these problems, pharmacotherapy of ischemic stroke should correspond to the standards and have a high level of quality (3, $9,10)$. Adherence to the medications for secondary prevention as well as treatment efficacy should be measured, registered, and monitored (11).

The Ljubljana Charter on reforming health care from June 19th, 1996 outlines the main principles of improvement in the field of healthcare for the European countries. The European Member States of the World Health Organization (WHO) processed these principles. According to this document, the constant improvement of medical care and its efficacy is the primary basis of health care system advancement (12). WHO defines the quality of medical care as a complex of characteristics that prove the correlation of medical aid with the needs of a patient (population), his expectations, and the current state of science and technology development (13).

According to the official data, about 146000 strokes occur per year in Ukraine. The death rates are 100896 cases per year and 126.5 deaths per 100000 inhabitants annually. Herewith, the specialists performed only 215 thrombolysis procedures in 2015 and reported only very few thrombectomies at the Stroke Alliance for Europe conference in 2016 (14). Therefore, in native Ukrainian conditions, the quality of medical care for this group of patients should be studied more precisely because the surviving rates depend on it at large.

The clinical indicators for quality of medical care are the quantitative or qualitative indicants that have evidence or consensus of their direct influence on the quality of medical care. Clinical indicators for quality of medical care may be divided into general and specific. The first ones measure the aspects of medical care applied to the majority of patients (e.g., the share of specialists among other physicians, inpatient death rates, etc.). The specific clinical indicators for quality measure the separate aspects of treatment related to some certain disorders.

The path of evolution characterizes the process of identifying the specific clinical indicators for quality for ischemic stroke. In particular, in 2000 the Working Group on Stroke of the American Heart Association introduced the quality indicators for the structure, process, and outcomes of the six key treatment directions as follows: coordination of medical care; diagnosis; protection of nervous tissue; prevention of complications; initiation of the secondary prevention and recovery of functions (22). In 
2010, the US Stroke Performance Measure Consensus Group of several respected organizations that deal with medical care quality issues introduced ten most valuable clinical indicators for the quality of ischemic stroke management $(4,23)$. Six of these indicators relate to the prescription of pharmacotherapy at different stages of hospital stay (Table I).

Table I The most important clinical indicators for quality of ischemic stroke management in part of pharmacotherapy

\begin{tabular}{|c|l|}
\hline Clinical indicators for quality & \multicolumn{1}{|c|}{ The gist of the indicators for quality } \\
\hline 1. Thrombolytic therapy & $\begin{array}{l}\text { The share of patients who were delivered to the hospital during first } \\
\text { 2 hours after the onset of ischemic stroke signs (the last moment of } \\
\text { not having the stroke signs) and were given IV* Alteplase within } \\
\text { 3 hours after the onset of the disease }\end{array}$ \\
\hline $\begin{array}{c}\text { 2. Prevention of deep vein } \\
\text { thrombosis and its } \\
\text { complications }\end{array}$ & $\begin{array}{l}\text { The share of patients with ischemic stroke not being able to walk } \\
\text { who were prescribed prophylaxis of deep vein thrombosis and its } \\
\text { complications before the end of day 2 of hospital stay }\end{array}$ \\
\hline $\begin{array}{c}\text { 3. Antithrombotic therapy } \\
\text { prescribed during the first 2 } \\
\text { days of treatment }\end{array}$ & $\begin{array}{l}\text { The share of patients with ischemic stroke who were prescribed } \\
\text { antithrombotic agents (antiplatelets or anticoagulants) before the } \\
\text { end of day 2 of hospital stay }\end{array}$ \\
\hline $\begin{array}{c}\text { 4. Antithrombotic therapy } \\
\text { prescribed at discharge }\end{array}$ & $\begin{array}{l}\text { The share of patients with ischemic stroke who did not have } \\
\text { contraindications and were prescribed antithrombotic agents } \\
\text { (antiplatelets or anticoagulants) at discharge }\end{array}$ \\
\hline $\begin{array}{c}\text { 5. Anticoagulation prescribed } \\
\text { at discharge for patients } \\
\text { with atrial fibrillation (AF) }\end{array}$ & $\begin{array}{l}\text { The share of patients with ischemic stroke and AF who did not } \\
\text { have contraindications and were prescribed PO** anticoagulants at } \\
\text { discharge }\end{array}$ \\
\hline $\begin{array}{c}\text { 6. Lipid-lowering } \\
\text { pharmacotherapy prescribed } \\
\text { at discharge }\end{array}$ & $\begin{array}{l}\text { The share of patients with ischemic stroke who were prescribed } \\
\text { lipid-lowering agents (usually statins) at discharge }\end{array}$ \\
\hline
\end{tabular}

*IV - intravenous administration of medications,

**PO - oral administration of medications

Thus, the research aimed to study and analyze the quality of medical care of stroke patients at one of the hospitals in Lviv, Ukraine. The results of the indicator-for-quality analysis should justify the need for improvement of adherence of the healthcare providers to the evidence-based standards of medical care. 


\section{Planning (methodology) of research}

Type of the study: retrospective clinical-and-epidemiological; pharmacoepidemiological. Methods: clinical indicator analysis, statistical, and generalization.

The study was carried out according to the plan as follows:

1. Analysis of the scientific sources, medical-and-technological documents; search and selection of the clinical indicators for quality for ischemic stroke related to pharmacotherapy.

2. The clinical-and-epidemiological study was conducted based on the analysis of inpatient medical records of ischemic stroke cases, age and sex, comorbidities, duration of stay inspection, and statistical analysis.

3. Pharmaco-epidemiological study of the prescribed medicines structure, detection of agents that refer to the clinical indicators for quality.

4. Calculating the clinical indicators for quality, analysis of the results, and forming of conclusions.

\section{Materials and methods}

\section{Study design}

The retrospective analysis of the inpatient medical records $(n=151)$ with the prescription papers of the ischemic stroke patients based at the neurological department of Lviv Regional Clinical Hospital - a general hospital that provides high-quality medical aid for the population of Lviv region, other regions of Ukraine, and foreigners.

The clinical-and-epidemiological part of the analysis of the medical records consisted of identifying the diagnosis of ischemic stroke, specifying the gender and age of patients, the range of comorbidities, and the duration of hospital stay.

The pharmaco-epidemiological part of the study consisted of identifying medications for the pharmacological treatment of ischemic stroke, defining the correlation of its duration, the sequence with age, type, and the number of comorbidities. To study the impact of comorbidities on the estimated 10-year survival, the Charlson Comorbidity Index was identified.

The indicator analysis consisted of calculating the quantitative characteristics of the clinical indicators for quality. Most of the indicators were determined as the ratio between the number of objects that correspond to certain attributes (the indicator numerator) and the general number of the studied objects (the indicator denominator). So, the numeric value of the clinical indicator for quality was calculated as a ratio between the number of patients with ischemic stroke who had been prescribed certain required medications and 
the total number of patients with ischemic stroke at the analyzed hospital expressed in percentage (\%) as follows: (Numerator $\div$ denominator) x 100 .

The 1 st indicator for quality was to be calculated as a percentage ratio of the number of patients who received an intravenous infusion of Alteplase within 3 hours after the onset of stroke (the numerator) to the total number of patients with ischemic stroke in the analyzed hospital department (the denominator).

The 2nd and 3rd indicators for quality were calculated as a percentage ratio of the number of patients who had been prescribed the antithrombotic medications (antiplatelets or anticoagulants) before the end of the 2 nd day of hospitalization (the numerator) to the total number of patients with ischemic stroke in the analyzed hospital (the denominator).

The 4th indicator for quality was calculated as a percentage ratio of the number of patients who had been prescribed the antithrombotic medications (antiplatelets or anticoagulants) at discharge (the numerator) to the total number of patients with ischemic stroke in the analyzed hospital (the denominator).

The 5th indicator for quality was calculated as a percentage ratio of the number of patients with AF who had been prescribed oral anticoagulants at discharge (the numerator) to the total number of patients with ischemic stroke and AF in the analyzed hospital (the denominator).

The 6th indicator was calculated as a percentage ratio of the number of patients who had been prescribed the lipid-lowering agents at discharge (the numerator) to the total number of patients with ischemic stroke in the analyzed hospital (the denominator).

\section{Ethics Approval}

The study was carried out according to the hospital permission from July 10th, 2015, in Minutes No 01-14/1045. The Conclusion of the Human Research Ethics Committee of Danylo Halytsky Lviv National Medical University is in Minutes No 10, December 16th, 2019, the results were positive. All procedures were performed following the ethical standards of the Helsinki declaration and its amendments. The study did not include patients or other vulnerable groups.

\section{Data analysis}

The statistical data processing was performed with the help of Statistica 12 Trial software (StatSoft, 2012), and the quantitative measures (age, number of comorbidities, and duration of treatment) were compared. For the processed indicators the arithmetic mean was identified, the standard deviation (SD) specified, and the $95 \%$ confidence interval (CI) - the type of interval estimate that is computed from the observed data estimated. The normality of data distribution in samples was evaluated utilizing the Shapiro-Wilk test that rejects the hypothesis of normality when the p-value is less than or equal to 0.05 (failing the normality test allows to state with $95 \%$ confidence the data does 
not fit the normal distribution). Whereas the data distribution differs from the normal, the non-parameter method, namely the Kolmogorov-Smirnov test (where the chi-square goodness-of-fit test depends on adequate sample size for the approximations to be valid), was used. Differences were considered significant when $\mathrm{p}<0.05$ (24).

\section{Results}

Medical papers of patients - 90 males and 61 females (correlation 1.5:1) with ischemic stroke were analyzed in the study. The age range for male patients was within 33 - 96 years, the average age $(\mathrm{m} \pm \mathrm{SD})$ was $63.3 \pm 12.61$ years, median (interquartile range, IQR) $63(56-73)$ years. For women, the age range was within $37-87$ years and the average age was $70.2 \pm 12.53$ years, median (IQR) $75(65-80)$ years; $(\mathrm{p}<0.001)$. Therefore, differences due to age between men and women were significant.

The concomitant disorders were identified in the inpatient records of $98 \%$ of patients. Only 3 male patients had no registered comorbidities. Min number of comorbidities in male patients equaled $1, \max -12$, the average amount of comorbidities was 5.0 \pm 2.47 , median (IQR) $5(3-6)$ disorders. For females min amount of comorbidities also equaled $1, \max -14$, the average amount of comorbidities was $4.8 \pm 2.10$, median (IQR) $5(4-6)$ disorders; $(p>0.10)$, so the research groups of patients did not significantly differ from each other by the number of concomitant disorders. In the structure of comorbidities, the prevailing one was hypertension with a frequency of $84.8 \%$ of cases. Heart failure at different stages was diagnosed in $72.2 \%$ of patients, and $66.2 \%$ - ischemic heart disease. For men, the average value of the Charlson Comorbidity Index was 66.0 \pm 28.69 , median (IQR) $77(53-90)$. For women $-53.8 \pm 32.18$, median (IQR) 53 $(21-77) ;(\mathrm{p}<0.05)$. Thus, differences in estimated 10-year survival in the male and female groups were significant. For male patients, the min duration of hospital stay equaled 5 bed-days, max - 36 bed-days, the average duration of hospitalization was $14.0 \pm 6.64$ bed-days, median (IQR) $12(9-18)$ bed-days. For females, min duration of hospital stay equaled 3 bed-days, max -37 bed-days, average duration of hospitalization was $14.1 \pm 6.86$ bed-days, median (IQR) $13(10-17)$ bed-days; $(p>0.10)$, i.e. the studied groups had no statistically significant difference.

According to the inpatient medical records, no thrombolytic pharmacotherapy was prescribed to the patients at the analyzed hospital department for ischemic stroke patients. So, the 1 st indicator for quality was not calculated.

The starting point for accounting clinical indicators for quality 2-5 for the medical care of patients with ischemic stroke (Table I) was the prescription of antithrombotic therapy (anticoagulants and antiplatelets). As the clinical indicators for quality 2 and 3 both base on pharmacotherapy with antithrombotic agents, we assessed those in the complex. In general, antithrombotic therapy was prescribed to 104 patients with ischemic stroke $(68.9 \%)$. Herewith, it was prescribed on hospitalization days 1-2 (clinical 
indicators for quality 2 and 3$)$ to 99 patients $(65.6 \%$ of the total number of patients with ischemic stroke). During treatment and at discharge (clinical indicator for quality 4) anticoagulants were prescribed to 10 patients $(6.6 \%)$. The number of anticoagulant drug prescriptions according to the International Nonproprietary Names (INNs) is represented in Table II.

Table II Analysis of the anticoagulant agents' prescriptions for patients with ischemic stroke

\begin{tabular}{|c|c|c|c|c|c|c|}
\hline \multirow{2}{*}{ INN } & \multirow{2}{*}{ ATC-code } & \multicolumn{5}{|c|}{ Number of prescriptions } \\
\hline & & $\mathbf{n}$ & Share $(\%)^{*}$ & Day 1-2 & Another day & At discharge \\
\hline \multicolumn{7}{|c|}{ Medications for parenteral administration } \\
\hline Enoxaparin & B01AB05 & 94 & 62.3 & 91 & 3 & - \\
\hline Nadroparin & B01AB06 & 4 & 2.6 & 3 & 1 & - \\
\hline $\begin{array}{l}\text { Pentosan } \\
\text { polysulfate sodium }\end{array}$ & B01AB15 & 3 & 2.0 & - & 1 & 2 \\
\hline \multicolumn{7}{|c|}{ Medications for oral administration } \\
\hline Warfarin & B01AA03 & 7 & 4.6 & 4 & 1 & 2 \\
\hline Acenocoumarol & B01AA07 & 2 & 1.3 & 2 & - & - \\
\hline Dabigatran & B01AE07 & 8 & 5.3 & - & 1 & 7 \\
\hline
\end{tabular}

*Share of total $n=151$

Further analysis showed that antiplatelet pharmacotherapy agents were prescribed 73 times (48.3\% of the total ischemic stroke cases under investigation). On days 1 and 2 (clinical indicator for quality 3 ) antiplatelets were prescribed to 30 patients (19.9\%), and at discharge (clinical indicator for quality 4$)$ - to 41 patients $(27.2 \%)$.

Table III represents the number of prescribed antiplatelet medications according to certain INNs of medications. Both single and multiple component medications were prescribed to the patients. A mono-component drug was prescribed 70 times $(95.9 \%$ of the total number of hospitalized ischemic stroke cases). Three prescriptions $(4.1 \%)$ included several antiplatelets (which were different at the beginning and/or during treatment and were changed for other agents at discharge): Clopidogrel vs Triflusal, Clopidogrel vs Acetylsalicylic acid (ASA), combinations of ASA vs mono-component ASA. 
Table III Analysis of the antiplatelet agents' prescriptions for patients with ischemic stroke

\begin{tabular}{|l|c|c|c|c|c|c|}
\hline \multirow{2}{*}{ INN } & \multirow{2}{*}{$\begin{array}{c}\text { ATC- } \\
\text { code }\end{array}$} & $\mathbf{n}$ & Share (\%)* & Day 1-2 & Another day & At discharge \\
\cline { 5 - 7 } & B01AC04 & 20 & 13.2 & 3 & 2 & 15 \\
\hline Clopidogrel & B01AC06 & 23 & 15.2 & 14 & - & 9 \\
\hline Triflusal & B01AC18 & 1 & 0.7 & - & - & 1 \\
\hline Acetylsalicylic acid combinations & B01AC30 & 32 & 21.2 & 13 & 1 & 18 \\
\hline
\end{tabular}

*Share of total $n=151$

The analysis of the clinical indicator for quality 3 confirms that on days 1-2 of hospitalization the antithrombotic medications (anticoagulants or antiplatelets) were in general given to 129 patients $(85.4 \%)$. The investigation of the indicator for quality 4 shows that at discharge antithrombotics were prescribed to 51 patients $(33.8 \%)$.

The clinical indicator for quality 5 defines the prescription of anticoagulants to patients with AF at discharge. It means the share of patients with AF who had no contraindications and at discharge were prescribed oral anticoagulants. Among the analyzed cases, as much as 27 patients had AF. At discharge, only 9 of them $(33.3 \%)$ were prescribed pharmacotherapy with oral anticoagulants.

The clinical indicator for quality 6 for medical care of patients with ischemic stroke characterizes the indication of lipid-lowering agents (statins) at discharge from the hospital. Among 151 of patients with ischemic stroke, 72 of them $(47.7 \%)$ were prescribed statins in this case which corresponded to 73 statin prescriptions. The quantity of prescribed statins is represented in Table IV according to the INNs of the medications. The prevalence of all statin prescriptions belongs to Atorvastatin preparations (35.1\%).

Table IV The quantitative analysis of lipid-lowering pharmacotherapy

\begin{tabular}{|c|c|c|c|}
\hline \multirow{2}{*}{ INN or AN } & \multirow{2}{*}{ ATC-code } & \multicolumn{2}{|c|}{ Number of prescriptions } \\
\cline { 2 - 3 } & & Absolute & 2.6 \\
\hline Simvastatin & C10AA01 & 53 & 35.1 \\
\hline Atorvastatin & C10AA05 & 16 & 10.6 \\
\hline Rosuvastatin & C10AA07 & 4 & Share \\
\hline
\end{tabular}

*Share (of total $n=151$ ) 
Table $\mathrm{V}$ represents the quality of medical care provided to patients in the study according to the quantitative analysis of the available clinical indicators for quality.

Table $\mathbf{V}$ The value of the clinical indicators for quality for the pharmacotherapy of ischemic stroke

\begin{tabular}{|c|l|c|c|}
\hline $\begin{array}{c}\text { Clinical } \\
\text { indicator for } \\
\text { quality }\end{array}$ & \multicolumn{1}{|c|}{ Meaning } & $\begin{array}{c}\text { Quantitative } \\
\text { indicator, \% }\end{array}$ & $\mathbf{9 5 \% \text { CI, \% }}$ \\
\hline 1 & Thrombolytic therapy & Not defined & Not defined \\
\hline $2-3$ & $\begin{array}{l}\text { Antithrombotic prophylaxis and pharmacotherapy on } \\
\text { days 1-2 }\end{array}$ & 65.6 & $57.4-73.1$ \\
\hline 3 & Antithrombotic therapy, days 1-2 & 85.4 & $78.8-90.6$ \\
\hline 4 & Antithrombotic pharmacotherapy at discharge & 33.8 & $26.3-41.9$ \\
\hline 5 & Anticoagulation for patients with AF, at discharge & 33.3 & $16.5-53.9$ \\
\hline 6 & Lipid-lowering pharmacotherapy, at discharge & 47.7 & $39.5-55.9$ \\
\hline
\end{tabular}

\section{Discussion}

The quantitative assessment of medical care quality is a complicated and painstaking process $(15,16,17,18,19)$. It is performed through the identification and use of different criteria that characterize the three basic compounds of medical care. They are the structure, process, and outcomes of treatment (20) - i.e. clinical indicators for quality (21). Nowadays, the use of indicators for economic efficiency is also increasing, as they combine the expenses and the outcomes of treatment.

During the investigation of the clinical indicators for the quality of ischemic stroke pharmacotherapy in this study, several important issues were identified. According to the clinical guidelines, one of the most effective methods of conservative ischemic stroke treatment is thrombolytic pharmacotherapy $(3,9,25)$. The developed countries widely apply to this method $(1,25)$, while in Ukraine only an insignificant $1 \%$ share of patients gets it $(14,19)$. As this method was not used at the analyzed hospital department, we did not assess the quality indicator 1 for ischemic stroke.

Regarding antithrombotic pharmacotherapy on hospital days 1-2, one of the patients was prescribed 2 different antithrombotics at once (namely Enoxaparin and Acenocoumarol). Also, as noted in results, 3 patients were prescribed several different 
medications (some particular ones at the beginning and/or during the inpatient hospital stay, others - at discharge) as follows: Clopidogrel and Triflusal; Clopidogrel and ASA; ASA fixed combination and mono-component ASA. This is taken as one of the medication errors revealed during the analysis. The investigation of the anticoagulant agents' prescription as of clinical indicators for quality 2-3 and 5 showed the correlation with the common practice of anticoagulants use in patients with ischemic stroke, though in the analyzed share there was no problem with non-recommended heparin prescription as seen in other studies (8). However, underestimated anticoagulation with Warfarin for secondary prevention of ischemic stroke in patients with AF (8) is still underused in native Ukrainian conditions. The incorrectness of antithrombotic prescription also includes changing of several agents within the same group of medications during the hospital stay and at discharge.

The same relates to lipid-lowering pharmacotherapy. Herewith, a single certain drug was given to 71 patients $(98.6 \%)$. It should be admitted that one of the patients (1.4\%) was prescribed 2 different medications from the same pharmacotherapeutic group: Rosuvastatin at the beginning of treatment, and at discharge - Atorvastatin. This is considered to be an example of irrational pharmacotherapy as both medications have the same mode of action with none or slight differences in efficacy and safety $(26,27)$. Here, the expenses on pharmacotherapy might be aggravating and cause patient's nonadherence. In addition, the risk factors for statin adverse reactions are polypharmacy and overdose, at the same time being one of the most prevalent drug-related problems in Ukrainian patients (26).

The results of the study show that due to the clinical quality indicator 3 , the quality of medical care can be defined as high (from the moment of admission of the patient to the hospital as for antithrombotic therapy) if we assume that the analyzed share included no cases of required thrombolytic pharmacotherapy. It means that in this case at the analyzed hospital department specialists are well aware of the requirements of medicaland-technological documents regulating the procedure of medical care for this category of patients (15-19). The quality of medical care is also high enough regarding the prescription of anticoagulants for patients with ischemic stroke according to the results for clinical indicators for quality 2 and 3. Some hitches in quality of medical care were noticed at the stage of discharge from the hospital as might be seen from the meanings of the indicators for quality 4 to 6 . Moreover, it is important because prescribing of Warfarin (to the patients with AF, in particular) and other antithrombotic agents at discharge from the hospital have the level of evidence A (18). The attention should also be paid to the prescription of statins as lipid-lowering agents because the study shows that these medications were prescribed to less than half of patients with ischemic stroke.

The practice of providing the population-based multi-center analyses of the compliance towards clinical indicators for quality, including the ones focused on 
pharmacotherapy of acute ischemic stroke is a standard and a common practice all over the world $(1,3,11,28,23)$. Ukraine, in its turn, the research work in this direction is not carried out or stays at the basic level. Our pilot study of a quantitative assessment of the quality of medical care indicants found no parallel or similar native studies so far. Thereby, the design of the research provided and the obtained results have no analogy in Ukraine and may serve as an example of a quantitative assessment of medical care quality in the treatment of patients with acute ischemic stroke and also implemented into the same process with other disorders or clinical conditions.

The current research specifies in detail the clinical indicators for the quality of ischemic stroke management that relate to pharmacological treatment. Each available indicator was calculated and analyzed. As the previous studies deal with the number of drug consumption and issues of rational pharmacotherapy in case of ischemic stroke and other acute cerebrovascular accidents (29), the further focus should be done on medications that identify the clinical indicators for quality, namely: fibrinolytics (thrombolytics), antiplatelets, anticoagulants, and lipid-lowering agents mentioned in this study.

In our opinion, there are 3 ways of solving existing problems. They are: 1) Strict compliance with the current medical-and-technological documents (clinical guidelines, protocols, and standards of medical care) that are implemented into practice and regulate the procedure of medical care of patients should be provided. 2) Constant conformity of the provided medical care to clinical guidelines, protocols, and standards of medical care is to be monitored. 3) In case of detecting the nonconformity of the required management decisions directed at medical care of patients with ischemic stroke optimization, the measures (according to the evidence-based algorithms) should be taken immediately. We expect this will help to improve the performance and efficiency of medical care of patients with ischemic stroke, hence will boost its quality.

\section{Limitations}

The most important limitation of the conducted research was the inability to measure clinical indicators for quality 1 related to thrombolytic pharmacotherapy prescription during the first 2 hours after the onset of ischemic stroke signs and symptoms as it was not provided at the analyzed hospital department. It should be mentioned, that fibrinolytic medications are the first-line treatment option for patients with ischemic stroke who have no contraindications $(3,19,25)$. Hence, thrombolytic pharmacotherapy must play a significant role among the other indicators for quality in patients with acute ischemic stroke (21).

The other limitations of this study include the following issues. Firstly, conducting only a one-time measurement of the collected results that do not allow following the dynamics of the revealed problem. Secondly, the size of the sample was relatively modest 
that limits the evaluation of the general picture of the healthcare situation in Ukraine. Thirdly, another drawback is that the research was conducted only at one regional hospital of only one town. Therefore, the findings cannot be statistically generalized. It is necessary to provide further research with the bigger samples involving analysis of the medical records from different clinical bases all over the country.

\section{Conclusion}

Despite the clinical indicators for quality of medical care show that pharmacological treatment of the patients using antithrombotics at the admission to the hospital corresponded to standards and quality was defined as high, for the pharmacotherapy prescribed at discharge, the indicator analysis revealed existing problems. Two indicators for antithrombotic and one for lipid-lowering pharmacotherapy revealed low rates. These outcomes mean poor quality of pharmacotherapeutic care for post-stroke patients. The complex of three algorithms was introduced to manage the problems and improve the quality of medical care.

\section{References}

1. Benjamin EJ, Muntner P, Alonso A, Bittencourt MS, Callaway CW, Carson AP et al. American Heart Association Council on Epidemiology and Prevention Statistics Committee and Stroke Statistics Subcommittee. Heart Disease and Stroke Statistics - 2019. Update: A Report from the American Heart Association. Circulation. 2019;139:e56-e528. Available from: https://www.ahajournals.org/doi/10.1161/CIR.0000000000000659.

2. Katan M, Luft A. Global Burden of Stroke. Semin Neurol. 2018;38(2):208-11. doi: 10.1055/s-00381649503.

3. Powers WJ, Rabinstein AA, Ackerson T, Adeoye OM, Bambakidis NC, Becker K et al. American Heart Association Stroke Council. 2018 Guidelines for the Early Management of Patients with Acute Ischemic Stroke: A Guideline for Healthcare Professionals from the American Heart Association/American Stroke Association. Stroke. 2018;49(3):e46-e110. Available from: https://www.ahajournals.org/doi/10.1161/STR.0000000000000158.

4. Freeman WD, Dawson SB, Raper C, Thiemann K, Josephson SA, Barrett KM. Neurohospitalists reduce length of stay for patients with ischemic stroke. Neurohospitalist. 2011;1(2):67-70. doi:10.1177/1941875210394202.

5. Basheti IA, Ayasrah SM, Ahmad M. Identifying treatment related problems and associated factors among hospitalized post-stroke patients through medication management review: A multi-center study. Saudi Pharm J. 2019;27(2), 208-19. doi: 10.1016/j.jsps.2018.10.005.

6. Di Simone E, Giannetta N, Auddino F, Cicotto A, Grilli D, Di Muzio M. Medication errors in the emergency department: Knowledge, attitude, behavior, and training needs of nurses. Indian J Crit Care Med. 2018;22:346-52. doi: 10.4103/ijccm.IJCCM_63_18. 
7. Jellinek-Cohen SP, Li M, Husk G. Enoxaparin dosing errors in the emergency department. World J Emerg Med. 2018;9(3):195-202. doi: 10.5847/wjem.j.1920-8642.2018.03.006.

8. Michaels AD, Spinler SA, Leeper BE, Ohman M, Alexander K P, Newby KL et al. Medication errors in acute cardiovascular and stroke patients: a scientific statement from the American Heart Association. Circulation, 2010;121:1664-82. Available from: https://www.ahajournals.org/doi/10.1161/CIR.0b013e3181d4b43e.

9. Ormseth CH, Sheth KN, Saver JL, Fonarow GC, Schwamm LH. The American Heart Association's Get with the Guidelines (GWTG)-Stroke development and impact on stroke care. Stroke and Vascular Neurology, 2017; 2:e000092. doi: 10.1136/svn-2017-000092. Available from: https://svn.bmj.com/content/2/2/94.

10. Turner GM, Calvert M, Feltham MG, Ryan R, Finnikin S, Marshall T. Clinical and Demographic Characteristics Associated With Suboptimal Primary Stroke and Transient Ischemic Attack Prevention: Retrospective Analysis. Stroke. 2018;49(3):682-7. Available from: https://www.ahajournals.org/doi/10.1161/STROKEAHA.117.020080.

11. Ung D, Kim J, Thrift AG, Cadilhac DA, Andrew NE, Sundararajan V et al. Promising Use of Big Data to Increase the Efficiency and Comprehensiveness of Stroke Outcomes Research. Stroke. 2019;50:1302-9. Available

from: https://www.ahajournals.org/doi/10.1161/STROKEAHA.118.020372.

12. The Ljubljana Charter on Reforming Health Care. BMJ. 1996;312(7047):1664-5. Available from: http://www.euro.who.int/en/publications/policy-documents/the-ljubljana-charter-on-reforminghealth-care,-1996.

13. Vuori HV. Quality assurance of health services: concepts and methodology: Copenhagen: Regional Office for Europe. World Health Organization; Albany, N.Y.: WHO Publications Centre: 1982. 127 p. Available from: https://trove.nla.gov.au/version/26291550.

14. Emmett E, Stevens E, Wang Y, McKevitt C, Wolfe C DA. The Burden of Stroke in Europe Report. King's College London for the Stroke Alliance for Europe (SAFE): 2017. Available from: https://www.stroke.org.uk/sites/default/files/the_burden_of_stroke_in_europe__challenges_for_policy_makers.pdf.

15. Ischemic stroke (emergency, primary, secondary (specialized) medical care, medical rehabilitation). Unified clinical protocol of medical care. [Internet]. Order of the Ministry of Health of Ukraine; No.602, 2012, Aug 3 [cited 2018 Jul 5]. Available from: https://zakon.rada.gov.ua/rada/show/v0602282-12\#n2.

16. Rehabilitation, prevention and treatment complications and discharge planning for ischemic stroke. Adapted clinical guideline based on evidence. [Internet]. Order of the Ministry of Health of Ukraine; No.602, 2012, Aug 3 [cited 2018 Jul 10]. Available from: http://mtd.dec.gov.ua/images/dodatki/2012_602/2012_602dod5AKN.pdf.

17. Recommendations for the management of patients with ischemic stroke and transient ischemic attack. Adapted clinical guideline based on evidence. [Internet]. Order of the Ministry of Health of Ukraine; No.602, 2012, Aug 3 [cited 2018 Jul 8]. Available from: https://zakon.rada.gov.ua/rada/show/va602282-12\#n4. 
18. Modern principles of diagnosis and treatment of patients with acute ischemic stroke and transient ischemic attack. Adapted clinical guideline based on evidence. [Internet]. Order of the Ministry of Health of Ukraine; No.602, 2012, Aug 3 [cited 2018 Jul 15]. Available from: https://dec.gov.ua/wpcontent/uploads/2019/11/2012_602dod1akn.pdf.

19. Systemic thrombolysis in ischemic stroke (emergency, secondary (specialized) medical care. Unified clinical protocol of medical care. [Internet]. Order of the Ministry of Health of Ukraine; No.602, 2012, Aug 3 [cited 2018 Jul 24]. Available at: https://zakon.rada.gov.ua/rada/show/vb602282$12 \#$ n3.

20. Donabedian A. The Quality of care: how can it be assessed? JAMA, 1988;12:1743-8. doi: 10.1001/jama.260.12.1743.

21. Mainz J. Defining and classifying clinical indicators for quality improvement: Int J Qual Health Care. 2003;15(6):523-530. Available from: https://doi.org/10.1093/intqhe/mzg081.

22. Measuring and improving quality of care: A report from the American Heart Association/American College of Cardiology First Scientific Forum on Assessment of Healthcare Quality in Cardiovascular Disease and Stroke, 2000;31(4):1002-12. doi: 10.1161/01.cir.101.12.1483.

23. Reeves MJ, Parker C, Fonarow GC, Smith EE, Schwamm LH. Development of stroke performance measures: definitions, methods, and current measures. Stroke. 2010;41(7):1573-80. Available from: https://www.ahajournals.org/doi/10.1161/STROKEAHA.109.577171.

24. Peacock J, Peacock P. Oxford Handbook of Medical Statistics. Oxford University Press: 2011. 544 p.

25. Cooray C, Mazya M, Mikulik R, Jurak L, Brozman M, Ringleb P et al. Safety and Outcome of Intravenous Thrombolysis in Stroke Patients on Prophylactic Doses of Low Molecular Weight Heparins at Stroke Onset. Stroke, 2019;50:1149-55. doi: 10.1161/STROKEAHA.118.024575.

26. Gorodnycha O, Zimenkovsky A, Kostyana K. Drug-related problems associated with use of statins in Ukraine: a hospital-based study. Pharmacia. 2016;63(4):29-34.

27. Wittich CM, Burkle CM, Lanier WL. Medication errors: an overview for clinicians. Mayo Clin Proc. 2014;89(8):1116-25. Available from: https://doi.org/10.1016/j.mayocp.2014.05.007.

28. Lindsay PM, Kapral MK, Holloway R, Gladstone DJ, Tu JV, Laupacis A, Grimshaw JM. Canadian Stroke Quality of Care Study: Identification of performance indicators for acute stroke care. CMAJ. 2005;172(3):363-5. doi: 10.1503/cmaj.045310.

29. Levytska OR, Hromovyk BP, Unhurian LM, Kostyana KV. Clinical-epidemiological and pharmacoepidemiological investigation of acute cerebrovascular accidents. Journal of Applied Pharmaceutical Science. 2017;7(07):168-75. doi: 10.7324/JAPS.2017.70725. 


\title{
Procena pokazatelja kvaliteta medicinske nege za farmakoterapiju kod pacijenata sa ishemijskim moždanim udarom: bolnička studija
}

\author{
Oksana Levitska ${ }^{1}$, Bohdan Hromovik ${ }^{1}$, Tetiana Rivak ${ }^{2}$ *, \\ Katerina Kostiana ${ }^{2}$
}

\author{
${ }^{1}$ Odeljenje za organizaciju i ekonomiju u farmaciji \\ ${ }^{2}$ Odeljenje za kliničku farmaciju, farmakoterapiju i medicinsku standardizaciju \\ Danilo Halitski Lviv, Nacionalni Medicinski Univerzitet, 79010, ul. Pekarska 69, Lviv, \\ Ukrajina
}

*Autor za korespondeciju: Tetiana Rivak, e-mail: tanusha1905@gmail.com

\begin{abstract}
Apstrakt
Ishemijski moždani udar spada u vodeće uzroke smrti i invaliditeta u svetu i Ukrajini. Stope preživljavanja zavise od kvaliteta pružene medicinske nege.

Istraživanje je imalo za cilj da analizira kvalitet medicinske nege u vezi sa farmakoterapijom ishemijskog moždanog udara. Klinički pokazatelji kvaliteta su kvantitativni ili kvalitativni dokazi ili konsenzus sa direktnim uticajem na ishod.

Šest se odnosi na farmakoterapiju akutnog ishemijskog moždanog udara (trombolitička, antiagregaciona, antikoagulantna i terapija za snižavanje lipida propisana u različitim fazama boravka u bolnici) koja je ispitana u ovoj retrospektivnoj analizi 151 pacijenata jedne od specijalizovanih bolnica u gradu Lviv.

Klinički pokazatelji kvaliteta medicinske nege pokazali su da je farmakološki tretman primenom antitrombotika (antiagregacionih lekova i antikoagulanasa) pri prijemu u bolnicu odgovarao standardima, a kvalitet je definisan kao visok sa stopama od 65,6\% i 85,4\% (od ukupnog broja pacijenata). Nakon otpusta, analiza farmakoterapije otkrila je probleme sa antitrombotskom (2 indikatora) i farmakoterapijom za snižavanje lipida (1indikator) sa stopama od 33,3\% i 47,7\%. Rezultati su pokazali postojanje problema povezanih sa farmakoterapijom. Za poboljšanje kvaliteta medicinske nege predložene su korektivne mere od tri algoritma.
\end{abstract}

Ključne reči: ishemijski moždani udar, kvalitet medicinske nege, lekovi, farmakoterapija, klinički indikator kvaliteta. 